\title{
A study on Online Shopping Behavior among the students
}

\author{
Ms. Neha Gupta/Dr. Deepali Bhatnagar \\ Amity University Rajasthan Jaipur
}

\begin{abstract}
On-line shopping is a recent era that has hiked in the domain of E-Business and is definitely going to be the future of shopping in the world. Everyone has entered to the smartphone world so it is easy to access apps according to their comfort and make their life better. At present there are millions of mobile apps likewise there apps for health, games, booking tickets, music, social networking, travel, banking, news, fitness, calendars and many more. The app stores add on 20,000 apps every month. Consumer's shop when and where they want, where they are comfortable with the products and the choice of shopping. The increase in technology provides good opportunities to the seller to reach the customer in much faster, easier and in economic way. India is penetrated by 204.1 million smartphone users as of 2016. The paper indicates that there is a difference between shopping by smartphone and traditional shopping. Thus this paper chats on upcoming trends, consumer behavior as well as its contribution to Digital India.
\end{abstract}

Keywords: Online-Shopping, Market Penetration, Trends, Consumer Behavior

\section{Introduction}

Currently the retail industry in India is accelerating. India is excited to grow to be a most important player in the retail market. By 2015, the total market size is estimated to be around US\$ 600 billion, thereby registering a CAGR of 7.45 per cent since 2000.The E-Commerce market is thriving and poised for robust growth in Asia. The e-Commerce market in India has enjoyed phenomenal growth of almost 50\% in the last five years. Although the trend of e-commerce has been making rounds in India for 15 years, the appropriate ecosystem has now started to fall in place. On the other hand the purchasing of product from traditional market is continuing since years. Many customers go for purchasing offline so as to examine the product and hold the possession of the product just after the payment for the product. With the increase of E-Commerce, the mobilemakers have made their way by introducing Mobile shopping by launching apps. The apps get more convenient as it's handy or portable and can be accessed from anywhere and anytime provided with the internet connection. India is one of the fastest growing retail e-commerce markets in 2015, growing at the rate of 129.5 per cent Y-oY. The growing number of Internet users in the country helped web merchants in steadily whittling away consumers' skepticism about buying goods and services online. As many as 106,086 websites are registered daily and more than $25 \%$ are for niche businesses.

The following are the objectives of the study:

\section{Objectives Of The Study:}

- To find out the behavior of the student and factors influencing while they buy the product

- To draw down the findings

- To give suggestions accordingly

\section{E-Commerce: Scaling Heights}

According to an SBI Research report, the e-retailing, which comprises online retail and online marketplaces, has become the fastest-growing segment in the larger market having grown at a CAGR of around 56 per cent during 2009-14. The e-retail market was around USD 6 billion in 2015. From an investment perspective, considerable funding in the e-Commerce ecosystem has led to emergence of new business models across B2B, B2C, Logistics Service Providers, Payment Wallets, Digital Advertising and Analytics. These investments have enabled the e-Commerce companies to leverage leading technology and related practices to reach out to millions of new online customers by delivering services more effectively and efficiently. In the last 18 months, the Government of India has announced several flagship programs namely, Digital India, Make in India, Start-up India, Skill India and Innovation Fund. The timely and effective implementation of these programs will support the e-Commerce eco-system to overcome the challenges related to ineffective rural internet penetration and lack of skilled manpower. For India Post, the government is keen to develop its distribution channel and other e-Commerce related services as a major revenue model going ahead, especially when India Post transacted business worth 280 crore INR in the cash-on-delivery (CoD) segment for firms such as Flipkart, Snapdeal and Amazon. Both these projects will have significant impact on increasing the reach of eCommerce players to generally non-serviceable areas, thereby boosting growth. 
Total e-Commerce size (\$ Billion)

\begin{tabular}{l|l|}
2013 & $\$ 2.9$ \\
\hline 2014 & $\$ 13.6$ \\
\hline 2015 & $\$ 16.0$ \\
\hline $2018^{\circ}$ & \\
\hline $2020^{\circ}$ & $\$ 40.3$ \\
\hline
\end{tabular}

Figure $1.52 z e$ of e-Commerce industry in Indis (indudes only B2C e-tall eacluding online trovel and chassifeds) Source: IMAI, Deloitte Analysis, *Estimated Numbers

The size of the total e-Commerce business is expected to rise by $\$ 101.9$ bn by 2020 according to the source of IMAI, Deloitte Analysis.

\section{Research Methodology}

The study is a descriptive one. The main aim behind the study was to identify the factors influencing the students. The research was carried out questionnaire method. The total respondents were 100 in size.

\section{SOURCE OF DATA:}

Primary Data: Primary data are those data, which are being collected by the researcher for the first time. They are the information received directly from general public, to whom the study was conducted. In this study, primary data was collected with the help of questionnaire given to students.

Secondary Data: The secondary data is collected through published sources like magazines, journals, articles etc.

\section{SAMPLING PROCEDURE:}

The sampling procedure used for the study is simple random sampling. Simple Random sampling is a type of probability sampling. There are no groups divided as such among the no of population. The size of the same is 100.

The following are the questions which are analyzed and interpreted accordingly.

\section{How often do you do online shopping?}

\begin{tabular}{|l|l|}
\hline \multicolumn{1}{|c|}{ Options } & \multicolumn{1}{c|}{ Respondents } \\
\hline Once in week & 10 \\
\hline Once in 15 days & 55 \\
\hline Only during Offers or Sale & 30 \\
\hline Very Rarely & 5 \\
\hline
\end{tabular}

\section{Question 1}

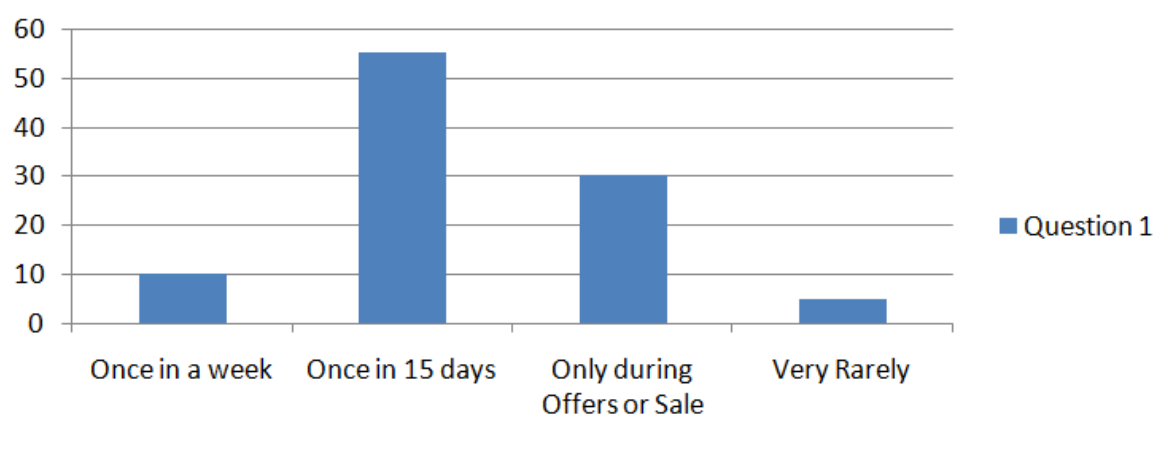

\section{Source: Primary Data}

Interpretation: Of the 100 students questioned, 55 responded they shop once in 15 months, while 30 nodded for shopping during Offers and sales and 10 students said they shop once in a week with 5 others stating, they shop online very rarely. 
2. How much do you usually spend on online shopping?

\begin{tabular}{|l|l|}
\hline \multicolumn{1}{|c|}{ Options (in Rs) } & \multicolumn{1}{c|}{ Respondents } \\
\hline $500-1000$ & 53 \\
\hline $1001-1500$ & 29 \\
\hline $1501-2500$ & 12 \\
\hline Above 2500 & 6 \\
\hline
\end{tabular}

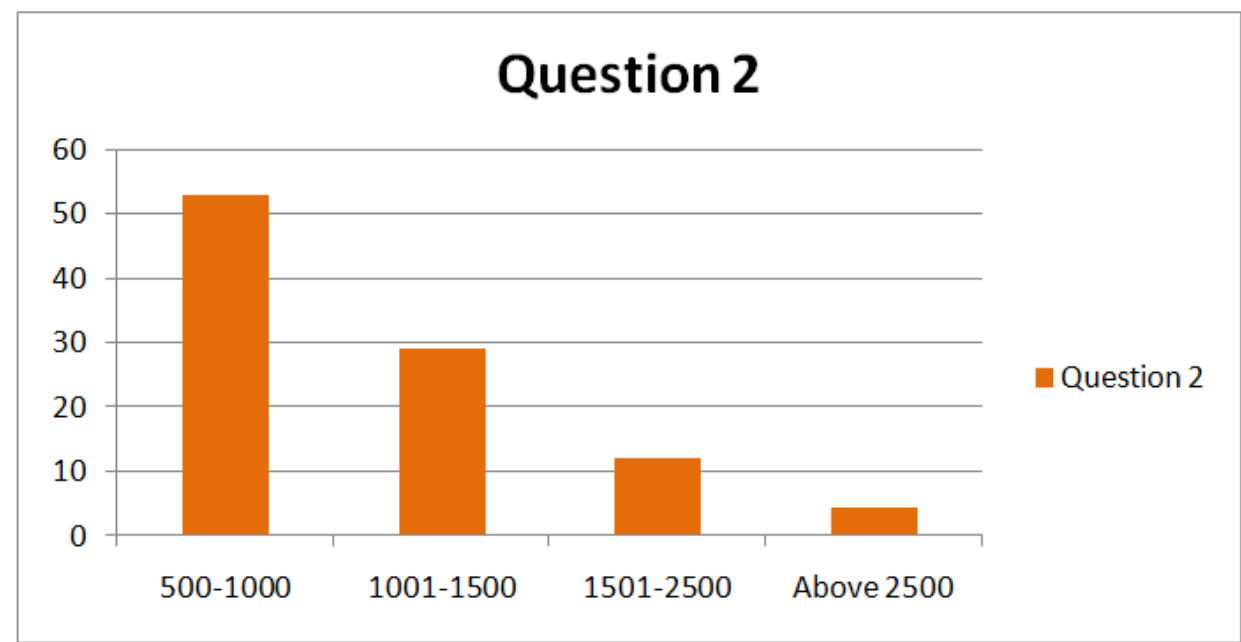

\section{Source: Primary Data}

Interpretation: Being respondents the hostel-students, spending is always a vital part for them. The above chart shows that 53\% of students shop in a range of 500-1000 rupees, followed by $29 \%$ in a range of 1001-1500 rupees, followed by 12 students and 6 students for the range of 1501-2500 and Above 2500 rupees respectively.

\section{Which website do you prefer the most among this?}

\begin{tabular}{|l|l|}
\hline \multicolumn{1}{|c|}{ Options } & \multicolumn{1}{c|}{ Respondents } \\
\hline Amazon & 29 \\
\hline Flipkart & 34 \\
\hline Snapdeal & 25 \\
\hline Jabong & 12 \\
\hline
\end{tabular}

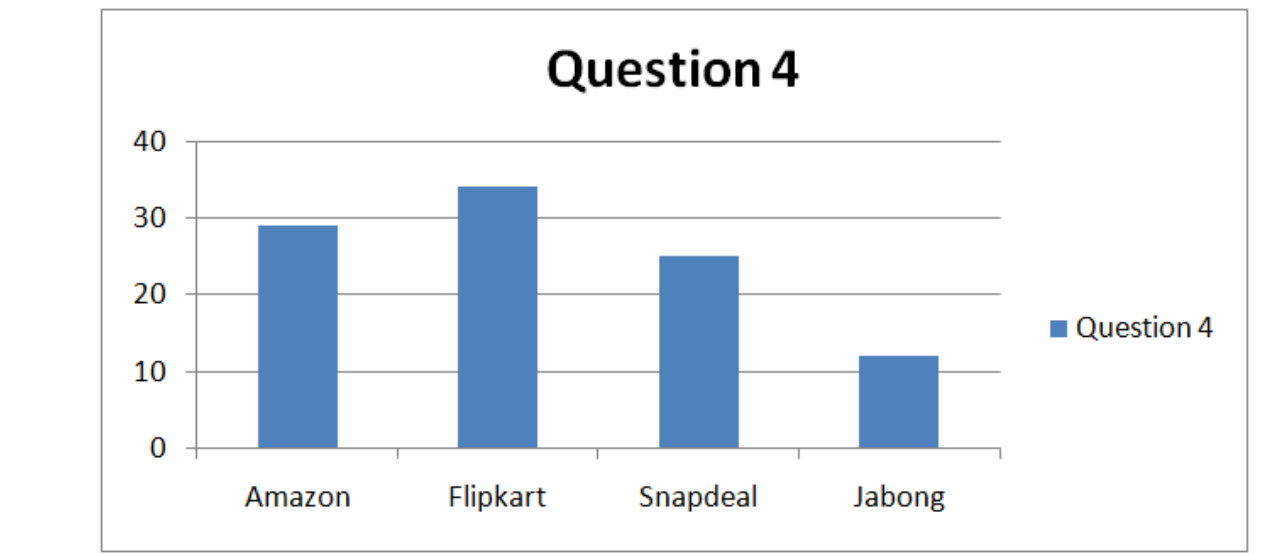

\section{Source: Primary Data}

Interpretation: Out of the leading e-commerce websites, Flipkart ranks first taking 34\% of respondents, followed by international rival Amazon with 29\% and Snapdeal with 25\%. Jabong settles with $12 \%$ of the total respondents.

4. What is the best thing you like about shopping online?

\begin{tabular}{|l|l|}
\hline \multicolumn{1}{|c|}{ Options } & \multicolumn{1}{|c|}{ Respondents } \\
\hline Variety of brands & 26 \\
\hline Price & 43 \\
\hline Timely Delivery & 12 \\
\hline All of the above & 19 \\
\hline
\end{tabular}




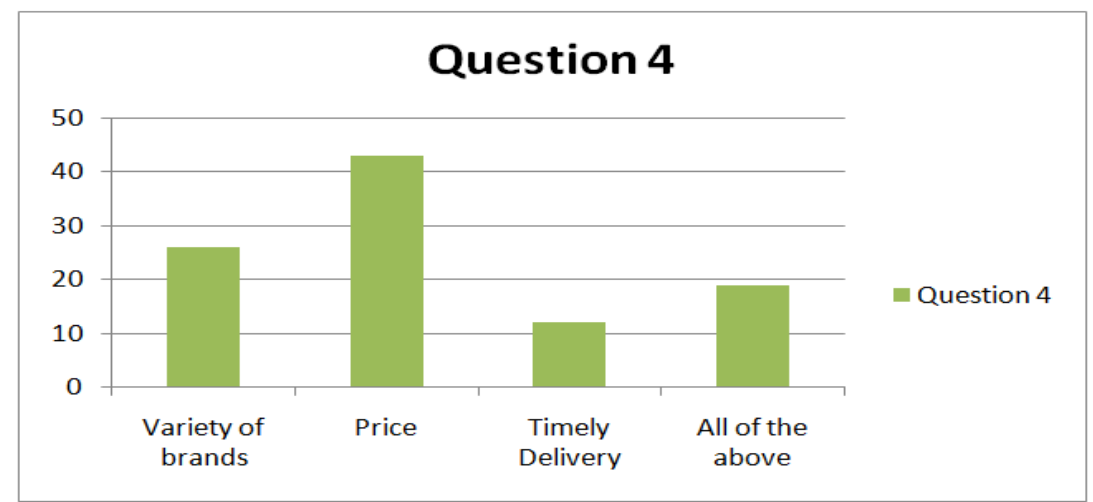

Source: Primary Data

Interpretation: The above chart clearly mentions that price $(43 \%)$ is the first stimuli that influence them while buying the product online. Second is the Variety of brand (26\%), while Timely Delivery (12\%) takes $3^{\text {rd }}$ Place. $12 \%$ of the respondents feel all the three act as stimuli for them.

5. Do you wait for festive seasons for shopping?

\begin{tabular}{|l|l|l|}
\hline \multicolumn{1}{|c|}{ Options } & \multicolumn{1}{c|}{ Respondents } \\
\hline Yes & 89 \\
\hline No & 11 & \\
\hline
\end{tabular}

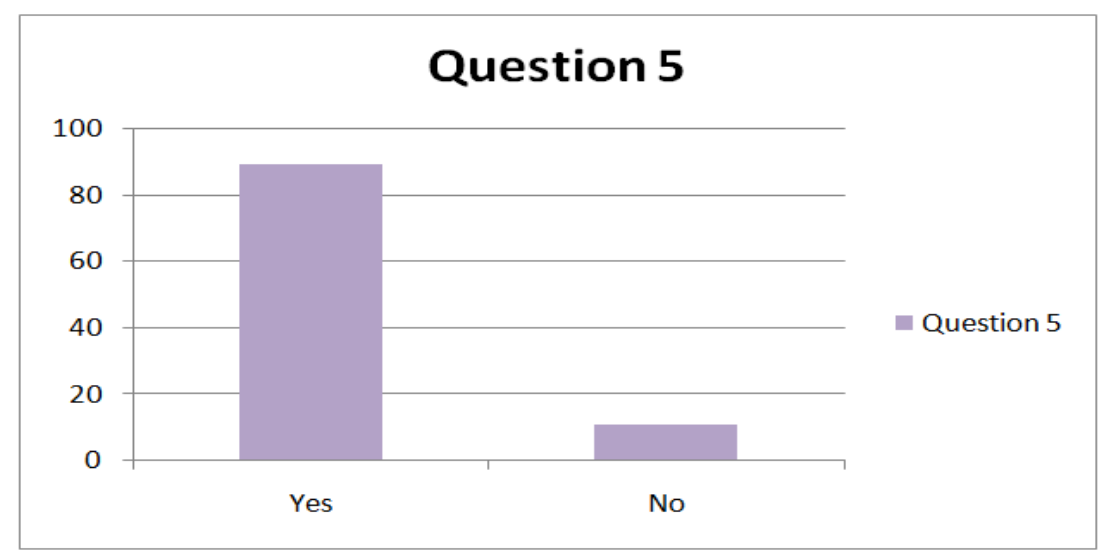

\section{Source: Primary Data}

Interpretation: $89 \%$ of the respondent saying that yes they do wait for festive seasons as it brings lots of offer. For e.g. Flipkart has Big Billion Day Offers. 11 \% respondent said they don't wait for such seasons for shopping.

6. Are the products same as it is shown in the app or website?

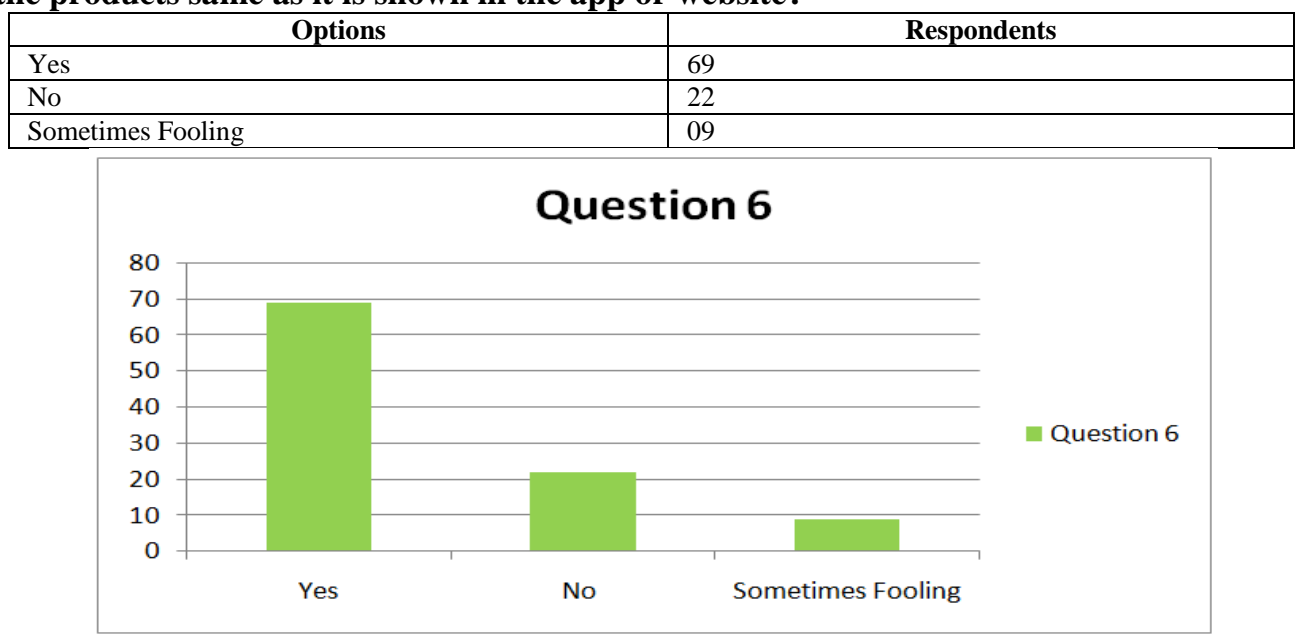

Source: Primary Data 
Interpretation: The above charts shows that $69 \%$ of the following respondents said the product were the same as shown in website. $22 \%$ said they were delivered fake products. $9 \%$ said they experienced sometimes foolishness.

7. Do you compare prices with other shopping apps or sites before buying?

\begin{tabular}{|l|l|}
\hline \multicolumn{1}{|c|}{ Options } & \multicolumn{1}{c|}{ Respondents } \\
\hline Always & 89 \\
\hline Sometimes & 7 \\
\hline Never & 4 \\
\hline
\end{tabular}

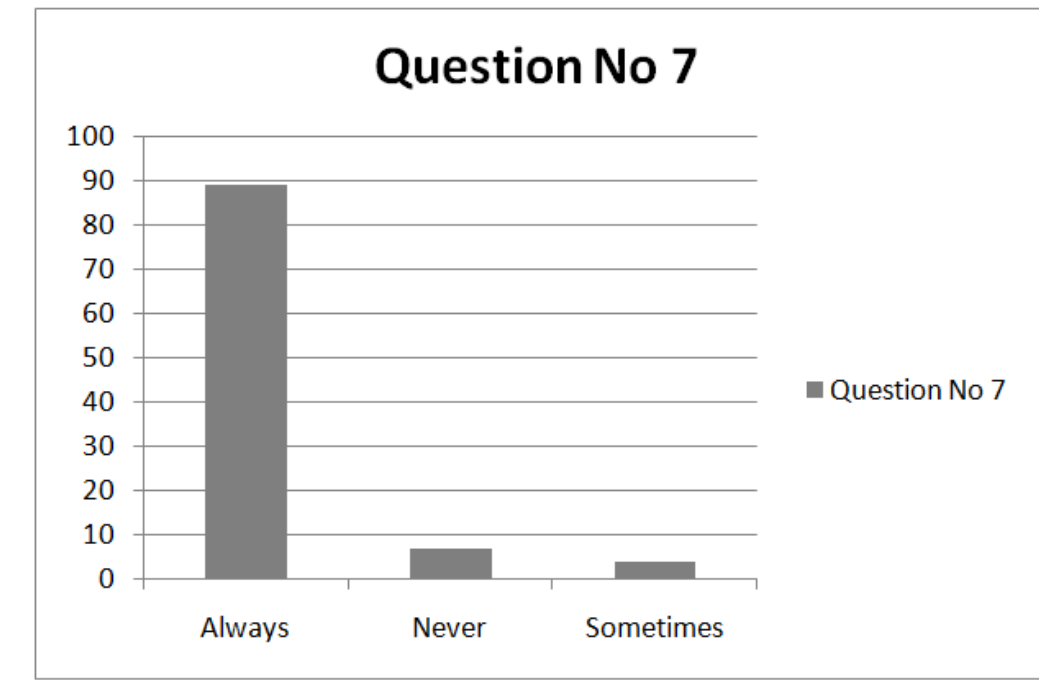

Source: Primary Data

Interpretation: It comes as a surprise that out of all the 100 respondents, majority of the respondents (89\%) said they do check and compare prices with other online mobile apps. $7 \%$ said they don't compare prices while $4 \%$ said they do but sometimes.

8. What do you buy the most among these following items?

\begin{tabular}{|l|l|}
\hline \multicolumn{1}{|c|}{ Options } & \multicolumn{1}{c|}{ Respondents } \\
\hline Clothing & 36 \\
\hline Gadgets & 24 \\
\hline Footwear & 26 \\
\hline Books & 14 \\
\hline
\end{tabular}

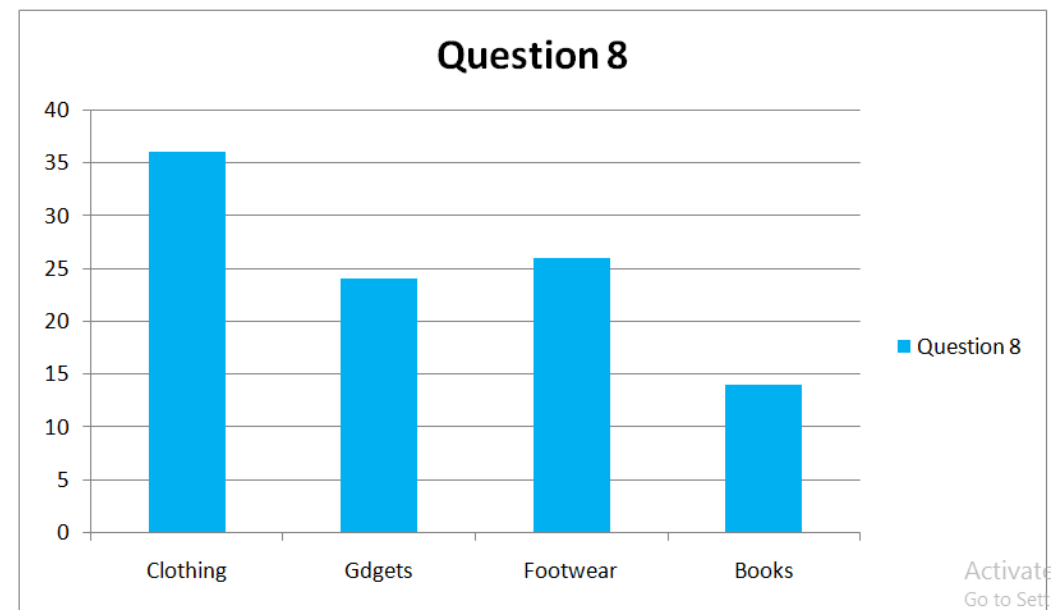

Source: Primary Data

Interpretation: $36 \%$ of the students said that they shop clothing, $24 \%$ said they buy gadget (Computer, peripherals, Mobile and Accessories). 26\% said they shop footwear the most, while 14\% prefer buying books the more. 
9. Have you ever experienced any fraud while paying online?

\begin{tabular}{|l|l|}
\hline \multicolumn{1}{|c|}{ Options } & \multicolumn{1}{c|}{ Respondents } \\
\hline Once & 10 \\
\hline Twice & 8 \\
\hline More than Twice & 5 \\
\hline Never & 77 \\
\hline
\end{tabular}

Interpretation: Majority with $77 \%$ said they never experienced any fraud, while 10 said they experienced it once. $8 \%$ said they had twice the experiences. While with $5 \%$ respondents, the fraud has occurred more than twice.

10. Are you satisfied with the after sale service of the e-tailers?

\begin{tabular}{|l|l|}
\hline \multicolumn{1}{|c|}{ Options } & \multicolumn{1}{c|}{ Respondents } \\
\hline Highly Satisfied & 56 \\
\hline Satisfied & 24 \\
\hline Not-Satisfied & 14 \\
\hline Extremely Not-Satisfied & 6 \\
\hline
\end{tabular}

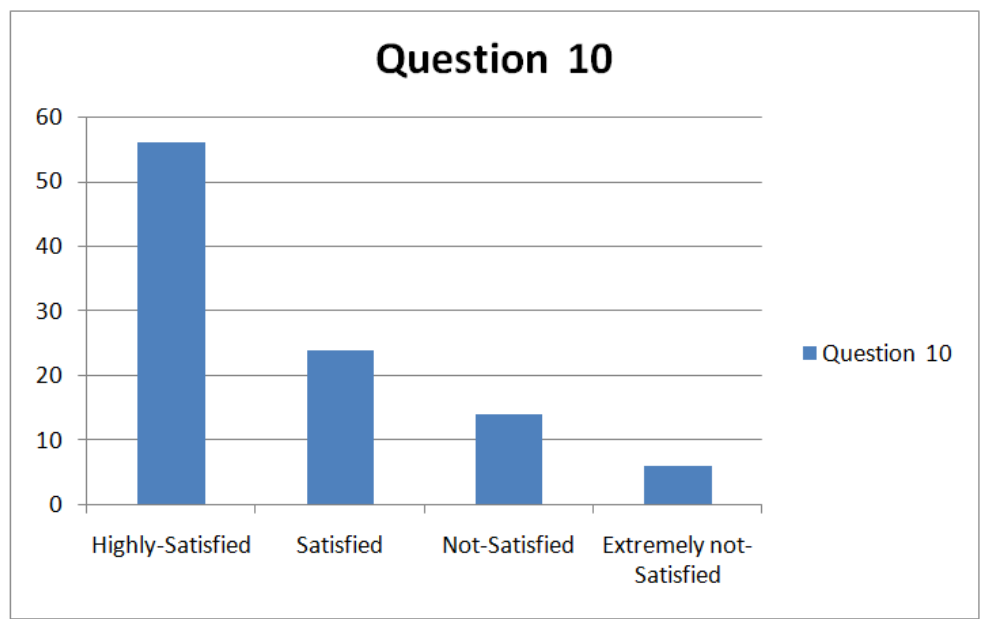

Interpretation: E-tailers do promise of many after sale services like guarantee, warranty, easy EMI, Easy return policy etc. The above chart shows that $56 \%$ respondents are high satisfied with the after sale service. While $24 \%$ said they were satisfied, $14 \%$ said they were not-satisfied and $6 \%$ said extremely not satisfied.

\section{Findings \& Recommendation:}

1. $55 \%$ of the respondents shop atleast once in 15 days. This creates a huge base of customer for e-tailers presently as well as for the coming future.

2. Most of the students spend 500-1000 rupees in a single shot shopping. There is a great demand for the products in this range that is economical as well as qualitative to them.

3. Indian e-tailer Flipkart has been a hit since its arrival. Even the survey shows it. However, the international rival Amazon is also not way behind.

4. Price plays an important role. Offers, discounts as well as Festive seasons are a big hit which has maximum footfalls.

5. Clothing and apparels are the highest buying products online.

6. The respondents face major problems on theft of credit card information, and lack of security on online payments. Implementing precautionary steps to solve these problems shall create consumer confidence on online shopping.

7. A special set of shopping can be created in view of students by giving offers, discounts, etc.

\section{Conclusion}

In conclusion, having access to online shopping has truly revolutionized and influenced our society as a whole. Factor analysis results reveal that Experimental Uniqueness, Customer Service and Convenience tend to be three significant dimensions as to why customers prefer internet shopping. Today there is radical change in the entire scenario. Everything in today's world is E prefixed like Electronic Data Interchange, E-Mail, EBusiness and E-Commerce. A key outcome of the technology revolution in India has been connectivity, which has fuelled unprecedented access to information. This use of technology has opened new doors and 
opportunities that enable for a more convenient lifestyle today. Online shopping is a vast growing technology. If it is properly utilized with assured safety and security for the transactions, it will thrive into a highly competitive and dynamic environment. Thus, a consumer being the king of the market needs a treatment like king. Even though the internet is often referred to as a borderless market, there are still some barriers to overcome.

\section{References}

[1]. http://www.livemint.com/Industry/jejcIGVMt1DbB8vKdhvglI/Foreignretailers-express-concernsover- retail.html (First Published: Wed, Nov 07 2012.) (07/11/12)

[2]. Peterson, R. A., Bal Subramanian, S., \& Bronnenberg,B. J. (1997), "Exploring the implications of the Internet for consumer marketing", Journal of Academy of Marketing Science, Vol. 24, No. 4, pp. 329-346.

[3]. Barkhi, R. and Wallace, L. (2007) "The impact of personality type on purchasing decision in virtual stores", Information Technology Management, Vol. 8 No. 4, pp. 313-30

[4]. Hsu, C.L. and Lu, H.P (2004) "Why do people play on-line games? An extended TAM with social influence and flow experience", Information and Management, Vol. 41 No. 7, pp. 853-68.

[5]. Zhou L., Dai, L. and Zhang, D. (2007) “Online shopping acceptance model - a critical survey of consumer facto 